\title{
INFLAMMATORY CELLS IN GASTRIC CANCER: PROMOTING THE TUMOUR OR PROTECTING THE HOST?
}

\author{
Tatjana Tone ${ }^{1, \#}$, Elīna Tauvēna ${ }^{1}$, Ilze Štrumfa ${ }^{1}$, and Jānis Gardovskis ${ }^{2}$ \\ 1 Department of Pathology, Rīga Stradinš̌ University, 16 Dzirciema Str., LV-1007, Rīga, LATVIA \\ 2 Department of Surgery, Rīga Stradiṇš University, 16 Dzirciema Str., LV-1007, Rīga, LATVIA \\ \# Corresponding author, Tatjana.Tone@rsu.lv
}

Contributed by Jānis Gardovskis

\begin{abstract}
The study represents a comprehensive retrospective morphological profiling of gastric carcinoma in order to reveal associations between certain tumour-infiltrating inflammatory cells and clinical and/or pathological parameters. Patients' age and gender, the extent of local tumour spread (pT), presence of metastases in regional lymph nodes $(p N)$, tumour grade $(G)$ as well as type according to World Health Organisation (WHO) and Lauren classifications were assessed in 211 consecutive surgically resected gastric carcinomas. Tumour-infiltrating inflammatory cells including eosinophils, neutrophils and lymphocytes were counted within the cancer stroma in five randomly selected high-power fields representative of the tumour. Descriptive statistics, Mann-Whitney and Kruskal-Wallis tests were applied; $p<0.05$ was considered significant. Higher number of stromal eosinophils was associated with absence of metastases in regional lymph nodes (pNO) and histological structure of adenocarcinoma by WHO classification $(\mathrm{p}=0.005$ and $\mathrm{p}=0.002$, respectively). Higher count of stromal neutrophils showed significant associations with younger age (less than 65 years), and intestinal type by Lauren classification ( $\mathrm{p}=0.029$ and $\mathrm{p}=0.007$, respectively). The density of stromal lymphocytes lacked any statistically significant association with the evaluated clinical or morphological parameters. In conclusion, the current study highlights the links between certain innate immune system cells and morphological features of gastric carcinoma.
\end{abstract}

Key words: stomach cancer, inflammatory infiltrate, tumour-infiltrating neutrophils, tumourinfiltrating eosinophils.

\section{INTRODUCTION}

Despite the declining global incidence, gastric cancer is the $5^{\text {th }}$ most frequently diagnosed cancer worldwide and the $3^{\text {rd }}$ leading cause of cancer-induced death. In United States, more than 70000 cases are diagnosed every year, corresponding to the incidence of 7.4 per 100000 inhabitants each year. According to data provided by the Surveillance, Epidemiology, and End Results system, the disease results in 3.4 death cases per 100000 persons (Bray et al., 2018; Anonymous, 2019; 2020).

Several research teams have studied inflammatory infiltration in colorectal tumours yielding significant correlations between the densities of tumour-infiltrating inflammatory cells and disease-free survival after curative surgery. Most such studies have been concentrated on tumour-infiltrating lymphocytes, which are believed to participate in immune reaction against tumour cells (Kim et al., 2007; Suzuki et al., 2010; Piazuelo et al., 2019). There are only a few reports about tumour-infiltrating inflammatory cells in gastric carcinoma (Lee, 2018).

In practical pathology, the association of eosinophils with Hodgkin's lymphoma is classical. In gastric biopsies, high numbers of eosinophils are observed in the uncommon eosinophilic gastritis while occasional eosinophils are evident in most cases of gastritis. However, eosinophils are also frequently seen in many solid tumours. Although the role of eosinophils that are associated with tumour cells and stroma remains unclear, their granules are rich with different cytokines and growth factors that may exert both pro- or antitumorous effects (Lotfi et al., 2007).

Tumour-infiltrating lymphocytes (TILs) have been studied widely. Mostly, TILs have anti-tumour effects. Thus, in co- 
lorectal carcinoma, the presence of CD8+ T lymphocytes is associated with better prognosis. Similarly, in gastric cancer, TILs are associated with improved survival. In contrast, presence of B lymphocytes lacks a prognostic role (Naito et al., 1998; Scanlan et al., 2002; Lee et al., 2018).

Neutrophils can exhibit dual effect, either destroying tumour cells or promoting the invasive growth (Aeed et al., 1988; Welch et al., 1989). Neutrophils have been associated with more frequent distant metastasis due to capability to degrade the basal membrane (Huh, 2010).

The aim of the current study was to assess the importance of inflammatory cell infiltration in gastric cancer, exploring the correlations with clinical and morphological parameters.

\section{MATERIALS AND METHODS}

Study design and ethics statement. The study was designed as a retrospective morphological investigation of a representative group of consecutive, surgically treated gastric carcinoma cases. It was carried out in accordance with the Declaration of Helsinki and was approved by the Committee of Ethics of Rīga Stradiņš University, Rīga, Latvia.

Study group. Diagnostic histopathology reports and slides of gastric carcinoma were retrieved by archive search for consecutive patients who underwent radical surgical treatment of primary invasive gastric carcinoma in a single university hospital within a seven-year period (2008-2014). Cases were excluded from the study on the basis of the following characteristics of the patient or tumour: 1) tissue material limited to a biopsy; 2) palliative surgery only; 3) history of any preoperative non-surgical oncological treatment, e.g., chemotherapy; 4) pTis or pT1a carcinoma; and 5) non-epithelial tumour. The search strategy and criteria yielded 211 tumour cases. Demographic data (age and gender) were retrieved from the medical documentation.

Grossing and technological handling of the tissue samples. During the initial diagnostic evaluation, the surgical pathology materials were subjected to uniform protocolbased assessment including standardised grossing, sampling, processing and embedding. The protocol was based on the recommendations issued by the College of American Pathologists. All the tissue samples that were dissected during grossing were fixed in neutral buffered $10 \%$ formalin (Sigma-Aldrich, United States of America), processed by increasing grades of isopropanol, followed by incubation in xylene and paraplast (Diapath S.r.1., Bergamo, Italy) in the vacuum infiltration processor Tissue-Tek ${ }^{\circledR}$ VIPTM 6 (Sakura Seiki Co., Ltd., Nagano, Japan).

The processed tissue was embedded in paraplast (Diapath S.r.1.) using the tissue embedding system TES 99 (Medite GmbH, Burgdorf, Germany). After embedding, tissue samples from paraplast blocks were cut in five-micron-thick sections by microtome (Accu-cut SRM 200W, Sakura Finetek Europa B.V., the Netherland) on glass slides (Santaks, Yanheng Huida Medical Instruments Co., Ltd, China). The slides were routinely stained with haematoxylin and eosin by an automated tissue stainer (TST 44, Medite Medizintechnik, Germany) and covered by a cover glass (Prestige, Vemi S.R.L., Milano, Italy) using an automated cover slipper (DAKO, Glostrup, Denmark).

Morphological evaluation. Within the frames of the current study, all morphological details were evaluated by two researchers on haematoxylin-eosin stained tissue sections in order to reach consensus.

Tumours were classified into histological types according to the World Health Organisation classification (Lauwers et al., 2010) and Lauren classification (Lauren, 1965). Grading was performed in accordance with tumour cell differentiation. The spread of tumour was characterised by pT (representing the deepest invasion of the tumour in the gastric wall or invasion into adjacent organs), and $\mathrm{pN}$ (characterising the presence and number of metastases in surgically removed regional lymph nodes) according to pTNM classification, $7^{\text {th }}$ ed. (Edge, 2010). Tumours limited to pTis or pT1a were excluded from the study because of insufficient tissue material. To evaluate the inflammatory infiltrate, eosinophils, neutrophils and lymphocytes were counted in five randomly selected high-power microscopic fields (HPFs) representative of the tumour (Bankur, 2016). The presence of lymphoid follicles within the tumour and along the invasive front was evaluated as well.

Statistical analysis. Descriptive and analytical statistical methods were applied. Descriptive data were expressed as mean \pm standard deviation (SD) or relative frequency. The $95 \%$ confidence intervals were calculated for mean values and frequencies. Non-parametrical Mann-Whitney and Kruskal-Wallis tests were performed. The $p$-values of 0.05 were considered statistically significant.

\section{RESULTS}

Clinical and morphological characteristics. According to the search strategy and criteria, 211 surgically treated consecutive cases of gastric cancer were identified, including 83 females (39.3\% [95\% confidence interval: 30.8-47.1]) and 128 males $(60.7 \%$ [55.7-66.3]). The mean age was $65.7 \pm 12.0$ years (range, 24 to 85 years [63.5-66.5]) There were 80 patients younger than 65 years and 131 cases diagnosed at the age of 65 years or older. Advanced tumours predominantly as pT3-pT4 spread were found in 175 (82.9\% [80.7-85.3]) cases contrasting with only $36(17.1 \%$ [5.8-28.2]) patients presenting with pT1b-pT2 carcinoma. Metastases in regional lymph nodes were identified in 58 (27.5\% [23.5-30.4]) cases. High-grade (G3-G4) carcinomas were more frequent, diagnosed in 167 cases $(79.1 \%$ [76.1-81.8]). According to Lauren classification, there were $160(75.8 \%$ [56.2-63.7] intestinal carcinomas and 51 (24.2\% [13.7-34.2]) diffuse carcinomas. The clinical and morphological features of patients and tumours are highlighted in Table 1. 
Table 1. Clinical and morphological characteristics of gastric carcinoma in association with tumour-infiltrating inflammatory cells

\begin{tabular}{|c|c|c|c|c|c|}
\hline Characteristics & & Number of cases & $\begin{array}{c}\text { Eosinophils } \\
p \text { value }\end{array}$ & $\begin{array}{c}\text { Neutrophils } \\
p \text { value }\end{array}$ & $\begin{array}{c}\text { Lymphocytes } \\
p \text { value }\end{array}$ \\
\hline \multirow[t]{2}{*}{ Age, years } & $<65$ & 80 & 0.515 & 0.029 & 0.681 \\
\hline & $>65$ & 131 & & & \\
\hline \multirow[t]{2}{*}{ Sex } & Male & 128 & 0.293 & 0.984 & 0.490 \\
\hline & Female & 83 & & & \\
\hline \multirow[t]{4}{*}{ Depth of invasion } & pT1b & 11 & 0.631 & 0.554 & 0.107 \\
\hline & pT2 & 25 & & & \\
\hline & pT3 & 69 & & & \\
\hline & pT4 & 106 & & & \\
\hline \multirow[t]{3}{*}{ Lymph node involvement } & pNO & 50 & 0.005 & 0.721 & 0.132 \\
\hline & $\mathrm{pN}+$ & 158 & & & \\
\hline & $\mathrm{pNx}$ & 3 & & & \\
\hline \multirow[t]{2}{*}{ Grade } & $\mathrm{G} 2$ & 44 & 0.928 & 0.218 & 0.952 \\
\hline & G3,G4 & 167 & & & \\
\hline \multirow[t]{2}{*}{ Lauren classification } & Intestinal type & 160 & 0.542 & 0.007 & 0.133 \\
\hline & Diffuse type & 51 & & & \\
\hline \multirow[t]{2}{*}{ WHO classification } & Adenocarcinoma & 156 & 0.002 & 0.123 & 0.133 \\
\hline & Signet ring cell carcinoma & 38 & & & \\
\hline
\end{tabular}

Tumour-infiltrating inflammatory cells. The count of tumour-infiltrating stromal eosinophils ranged from 0 to 114 cells per HPF; mean $3.3 \pm 9.0$ cells per HPF [1.8-4.2]. There was statistically significant positive association between the number of tumour-infiltrating eosinophils and absence of metastases in regional lymph nodes $(p=0.005)$ as well as with histological type (adenocarcinoma vs signet ring cell carcinoma; $p=0.002$ ) as shown in Table 2 .

The number of tumour-infiltrating stromal neutrophils (Table 2) ranged from 0 to 126 cells per HPF; mean $6.0 \pm 15.0$ cells per HPF [3.9-8.0]. There was statistically significant positive association between the number of stromal neutrophils and younger age $(p=0.029)$ as well as with the tumour type by Lauren classification $(p=0.007)$.

The count of tumour-infiltrating stromal lymphocytes ranged between 0 to 143 cells per HPF; resulting in the mean value of $10.2 \pm 15.5$ cells per HPF [8.1-12.3]. The number of tumour-infiltrating lymphocytes lacked any statistically significant links with the evaluated clinical and morphological parameters of gastric carcinoma.

Tumour-infiltrating inflammatory cells and presence of lymphoid follicles at the tumour site and periphery. Lymphoid follicles (LF) in gastric cancer slides were observed in 155 cases $(73.5 \%$ [69.4-76.6]).

LF located at the site of tumour and on periphery from tumour was noticed in 104 cases $(49.3 \%$ [42.1-55.9])

The mean number of eosinophils around a tumour close to LF was $3.0 \pm 4.6$ cells per HPF [2.4-3.6] as shown in Table 3 . The average number of neutrophils in association with tumour and lymphoid follicles was $5.1 \pm 12.5$ cells per HPF [3.1-6.9]
Table 2. Peritumorous inflammatory cells

\begin{tabular}{l|c|c|c}
\hline $\begin{array}{c}\text { Type of peritumorouse } \\
\text { inflammatory cell }\end{array}$ & $\begin{array}{c}\text { Mean (cells per } \\
\text { HPF) }\end{array}$ & $\begin{array}{c}\text { Range (cells per } \\
\text { HPF) }\end{array}$ & CI \\
\hline Eosinophils & 3.3 & $0-114$ & $1.7-4.2$ \\
Neutrophils & 6.0 & $0-126$ & $3.9-8.0$ \\
Lymphocytes & 10.2 & $0-143$ & $8.1-12.3$
\end{tabular}

Table 3. Peritumorous inflammatory cells in association with lymphoid follicles on side of tumour and on periphery

\begin{tabular}{lccc}
\hline & $\begin{array}{c}\text { Mean (cells } \\
\text { per HPF) }\end{array}$ & CI & $p$ value \\
\hline $\begin{array}{l}\text { Lymphoid follicles on side of tumour } \\
\text { and eosinophil infiltration }\end{array}$ & 3 & $2.3-3.6$ & 0.49 \\
$\begin{array}{l}\text { Lymphoid follicles on side of tumour } \\
\text { and neutrophil infiltration }\end{array}$ & 5.1 & $3.1-6.8$ & 0 \\
$\begin{array}{l}\text { Lymphoid follicles on side of tumour } \\
\text { and lymphocytes infiltration }\end{array}$ & 11.7 & $8.3-13.7$ & 0 \\
$\begin{array}{l}\text { Lymphoid follicles on periphery and } \\
\text { eosinophil infiltration }\end{array}$ & 3.6 & $1.73-5.4$ & 0.14 \\
$\begin{array}{l}\text { Lymphoid follicles on periphery and } \\
\text { neutrophil infiltration }\end{array}$ & 4.3 & $2.6-5.3$ & 0 \\
$\begin{array}{l}\text { Lymphoid follicles on periphery and } \\
\text { lymphocytes infiltration }\end{array}$ & 10.4 & $7.9-12.9$ & 0
\end{tabular}

The average count of lymphocytes in association with tumour and lymphoid follicles was $11.7 \pm 17.3$ cells per HPF [8.3-13.7] (Table 3). There was a statistically significant association between the presence of lymphoid follicles (close to tumour as well as on periphery) and higher density of tumour-infiltrating lymphocytes $(p<0.001)$.

\section{DISCUSSION}

According to the GLOBOCAN data on worldwide agestandardised incidence rates of different cancers in 2018, gastric cancer ranks $5^{\text {th }}$ by incidence, being the $4^{\text {th }}$ most fre- 
quent malignant tumour in males and $7^{\text {th }}$ - in females. Gastric cancer represents $5.7 \%$ of the global cancer burden, including $7.2 \%$ of all malignant tumours in males and $4.1 \%$ - in females. By mortality, gastric cancer ranks $3^{\text {rd }}$ comprising $8.2 \%$ of global cancer mortality. It is the $3^{\text {rd }}$ most frequent oncological cause of death in males, representing $9.5 \%$ of cancer-caused mortality in males, and the $5^{\text {th }}-$ in females $(6.5 \%$ of oncological mortality in females) (Bray, 2018; Anonymous, 2020).

Although the causes of gastric cancer are not completely elucidated, infection with Helicobacter pylori, diet (excess of salted foods and lack of fresh fruits), alcohol consumption and smoking clearly contribute to the pathogenesis. Helicobacter pylori represents the main risk factor as almost $90 \%$ of non-cardia gastric cancer cases are attributable to long-lasting $H$. pylori gastritis. However, the worldwide prevalence of $H$. pylori infection is decreasing, paralleled by declining incidence of non-cardia gastric cancer. In contrast, the incidence of the cancer of gastric cardia is increasing because of the same risk factors that are responsible for oesophageal carcinoma, namely, obesity and gastrooesophageal reflux disease (GERD). In the context of the current study it is interesting to note that almost all risk factors of gastric cancer induce inflammation, but the local morphology and systemic components differ by the aetiological factor. H. pylori gastritis shows classic association with lymphoid follicles, and neutrophils are seen as a manifestation of activity. GERD can induce heterogeneous morphological changes including presence of lymphocytes and macrophages; or infiltration of neutrophils in severe/erosive cases, but presence of eosinophils represents the morphological hallmark of reflux. Obesity is associated with low-grade systemic inflammation (Mezale et al., 2017).

In the Western world, most gastric cancer cases are diagnosed in an advanced stage, significantly limiting the treatment options. Surgery is the mainstay of gastric cancer treatment (Rumba et al., 2017), especially for early carcinomas. Chemotherapy and radiotherapy can also be included in the treatment protocols. Regarding novel treatment options for advanced cancers, immunotherapy is considered promising. There are three approved immunotherapy options for gastric cancer. Ramucirumab represents a monoclonal antibody with function to inhibit tumour blood vessels, and is used for advanced gastric cancers or gastroesophageal cancers. Trastuzumab is used for patients with advanced HER2 positive gastroesophageal cancers. Immunomodulator - Pembrolizumab is advised for advanced PD-L1 positive gastric or gastroesophageal cancers (Chao, 2018).

Studies of tumour-infiltrating inflammatory cells represent a hot topic in medicine and biology, especially in light of personalised treatment and possibility to develop cancer vaccines (Wang et al., 2018). Despite the intense research in this direction, the results remain controversial. One of the possible sources of controversy is the dependence of data on the study model: either cell cultures, or animal studies, or evaluation of human tissues representing the whole complexity of morphological events in the tumour.

In the present study, we investigated tumour-infiltrating stromal eosinophils, neutrophils and lymphocytes. The numbers of eosinophils were found to be significantly ( $p<$ 0.002 ) higher in adenocarcinomas (mean $7.2 \pm 18.5$ cells per HPF [1.3-13.1]) compared to signet ring cell carcinomas (mean $2.5 \pm 4.5$ cells per HPF [1.8-3.2]). Eosinophils were also significantly $(p<0.005)$ increased in $\mathrm{pN} 0$ gastric cancers $(6.0 \pm 16.5$ cells per HPF, [1.5-10.6]) in comparison with $\mathrm{pN}+(2.3 \pm 4.1$ cells per HPF [1.6-2.9]) gastric cancers.

Eosinophils are granulocytic leucocytes that develop in the bone marrow from CD34+, CD117+ pluripotent haematopoietic stem cells. After maturation, they enter peripheral blood stream constituting about $1 \%$ of all leucocytes (Davis and Rothenberg, 2014; Varricchi, 2016). Eosinophils have abundant secretory granules in their cytoplasm. Under specific stimulation, e.g., infection, eosinophils can release numerous substances including eosinophil cationic protein, major basic protein, eosinophil peroxidase, eosinophil-derived neurotoxin, large number of interleukins (IL-1, IL-2 and others), interferon $\gamma$, growth factors, chemokines, platelet-activating factor etc. These substances can lead to cell death, or modulate (induce or inhibit) inflammatory response (Kita, 1996; Teruya-Feldstein et al., 1999; Lorena et al., 2003; Rothenberg and Hogan, 2006). Eosinophils are best known for their significance in the pathogenesis of allergic diseases, but they have also protective function against parasites and certain microorganisms (Yousefi et al., 2008; Huang and Appleton, 2016). Eosinophils can migrate to inflamed tissues or tumour mass. This migration depends on interaction of multiple cytokines, chemokines and adhesion molecules (Lorena et al., 2003). In experimental animal models, the tumour-supressing role of eosinophils has been elucidated in melanoma as well as in prostatic and colorectal carcinomas. The relevant mechanisms differ by the tumour. Thus, in melanoma eosinophils inhibit tumour growth (Varricchi et al., 2016), but in colorectal carcinoma they directly induce cancer cell death (Varricchi et al., 2016). In human cancers, including colorectal and gastric carcinomas, higher counts of eosinophils in peripheral blood and tumour tissue are associated with better survival after surgery (Caruso et al., 2002; Varricchi et al., 2016). In contrast, higher amount of eosinophils is associated with worse prognosis in Hodgkin's lymphoma and cervical cancer (Nielsen et al., 1999; von Wasielewski et al., 2000; Dorta et al., 2002; Xie et al., 2015; Bankur et al., 2016; Varricchi et al., 2016).

The conflicting results indicate that different cancers might have specific mediators that promote the tumour-enhancing or tumour-limiting effects of eosinophils. Our results are compatible with favourable impact of higher density of eosinophils. Thus, we observed statistically significantly higher count of tumour-infiltrating stromal eosinophils in patients lacking tumour metastases in the regional lymph nodes. The other positive association was observed between 
higher density of eosinophils in adenocarcinoma compared to signet ring cell carcinomas. It is well-known that adenocarcinomas are associated with better prognosis in comparison with signet ring cell carcinomas.

Piazuelo et al. (2008) reported on tissue eosinophilia in chronic antral gastritis. They found an association between higher numbers of eosinophils in the infiltrate and lower risk of gastric cancer. This represents another example of the protective effects of eosinophils in gastric carcinogenesis.

Neutrophilic leucocytes are the first inflammation-fighting cells, capable to perform phagocytosis and release of different antimicrobial substances (Uribe-Querol, and Rosales, 2015). Neutrophils can also release cytotoxic granules to kill or degrade cancer cell, as well as to produce cytokines or chemokines to recruit other immune and/or inflammatory cells (Gregory and Houghton, 2011; Tecchio et al., 2013). In clinical studies, several cancers, e.g., renal carcinoma, melanoma and lung carcinoma, exhibit poor prognosis in association with infiltrating neutrophils (Bellocq et al., 1998; Schmidt et al., 2005; Atzpodien and Reitz, 2008). It has been reported that neutrophils promote cancer cell migration and invasion as well as angiogenesis in the tumour (Ardi et al., 2007). Zhao et al., 2012 showed association between tumour-infiltrating neutrophils and presence of lymph node metastasis as well as with distant metastatic spread and advanced clinical stage. The ability of neutrophils to remodel extracellular matrix (Jensen et al., 2009) can explain the link with tumour invasion and metastatic spread. Hiramatsu et al. (2018) published study results of cancer-associated neutrophils in gastric cancer.

A high number of tumour-infiltrating neutrophils was associated with deeper invasion, presence of lymph node metastasis and worse overall survival (Hiramatsu et al., 2018). Our results showed statistical association between numbers of tumour-infiltrating stromal neutrophils and cancer type by Lauren classification and patient's age. Higher density of stromal neutrophils was found in intestinal gastric cancer compared to diffuse type as defined by Lauren classification $(p<0.007)$; as well as in younger patients, diagnosed with gastric cancer before the age of 65 years $(p=0.029 ; \mathrm{R}=$ 0.077). As intestinal type and younger age tend to be associated with better prognosis, our results differ from other studies, indicating the need for further studies to resolve the existing controversies that can be related to the balance between N1 and N2 subsets of neutrophils, differences in the genetic background of the regulation of inflammation or variable spectrum of causative factors in different populations (Jablonska et al., 2017; Silovs et al., 2018).

Lymphocytes are broadly classified as $\mathrm{T}$ and B lymphocytes. Development and maturation of B lymphocytes occurs in bone marrow, followed by migration to lymph nodes and spleen. B lymphocytes are responsible for humoral immunity. T lymphocytes develop in bone marrow and mature in thymus or lymph nodes. In general, lymphocytes representing the adaptive immunity are considered to have tumour-suppressing effects, although contrary effects have been ascribed to certain subpopulations (Nelson, 2010; Strumfa et al., 2017).

Tumour-infiltrating lymphocytes have been studied extensively in context of breast, colorectal, gastric and other cancers. Higher density of TILs is associated with better prognosis in patients with invasive breast carcinoma (Rathore et al., 2014) or melanoma (Hendry et al., 2017). Studies of $\mathrm{CD} 3+\mathrm{T}$ lymphocyte infiltration in colorectal cancers was followed by "Imunoscore®" development, which is strongly associated with disease-free and disease-specific overall survival (Pages et al., 2009). Similarly as colorectal tumours, gastric carcinoma exhibiting microsatellite instability has marked infiltration of lymphocytes and is associated with favourable prognosis (Bosman et al., 2010). Kang et al., 2016 found positive prognostic value with tumourinfiltrating lymphocytes in Epstein-Barr virus-associated gastric carcinomas. Meta-analysis of TIL in gastric cancer also showed association with better outcome of disease (Lee et al., 2018). However, our results showed no significant correlation between any clinical and morphological parameters and number of tumour-infiltrating lymphocytes.

In conclusion, our study has highlighted the role of innate immunity in gastric cancer showing positive associations between the tumour-infiltrating stromal eosinophils and neutrophils and clinicomorphological parameters in gastric carcinoma. Further research should be continued to improve understanding of the role of tumour-infiltrating inflammatory cells in gastric cancer.

\section{CONFLICTS OF INTEREST}

The authors declare no conflict of interest.

\section{REFERENCES}

Aeed, P. A., Nakajima, M., Welch, D. R. (1988). The role of polymorphonuclear leukocytes (PMN) on the growth and metastatic potential of 13762 NF mammary adenocarcinoma cells. Int. J. Cancer, 42, 748-759..

Anonymous (2019). Cancer Stat Facts: Stomach Cancer. http://seer.cancer.gov/statfacts/html/stomach.html (accessed 15 December 2019).

Anonymous (2020). Global Cancer Observatory. http://gco.iarc.fr (accessed 20 January 2020).

Ardi, V. C., Kupriyanova, T. A., Deryugina, E. I., Quigley, J. P. (2007). Human neutrophils uniquely release TIMP-free MMP-9 to provide a potent catalytic stimulator of angiogenesis. Proc. Natl. Acad. Sci. USA, 104, 20262-20267.

Atzpodien, J., Reitz, M. (2008). Peripheral blood neutrophils as independent immunologic predictor of response and long-term survival upon immunotherapy in metastatic renal-cell carcinoma. Cancer Bioth. Radiopharmaceut., 23 (1), 129-134.

Bankur, R., Rodrigues, C., Anjaly, D., Gopinathan, P. A., Bankur, P. K. (2016). Quantitative analysis of tumor-associated tissue eosinophilia in different histological grades of oral squamous cell carcinoma. Indian J. Dent. Res., 27, 463-467.

Bellocq, A., Antoine, M., Flahault, A., Philippe, C., Crestani, B., Bernauydin, J. F., Mayaud, C., Milleron, L., Baud, L., Cadranel, J. (1998). Neutrophil alveolitis in bronchioloalveolar carcinoma: Induction by tu- 
mor-derived interleukin-8 and relation to clinical outcome. Amer. J. Pathol., 152 (1), 83-92.

Bosman, F. T., Carneiro, F., Hruban, R. H., Theise, N. D. (2010). WHO Classification of Tumours of Digestive System. $4^{\text {th }}$ edn. Lyon. 417 pp.

Bray, F., Ferlay, J., Soerjomataram, I., Siegal, R. L., Torre, L. A., Jemal, A. (2018). Global cancer statistics 2018: Globocan estimates of incidence and mortality worldwide for 36 cancers in 185 countries. CA Cancer J. Clin., 68, 394-424.

Caruso, R. A., Bellocco, R., Pagano, M., Bertoli, G., Rigoli, L., Inferrera, C. (2002). Prognostic value of intramural neutrophils in advanced carcinoma in a high-risk area in Northern Italy. Mod. Path., 15 (8), 831-837.

Chao, J. How is immunotherapy changing the outlook for patients with stomach cancer? https://www.cancerresearch.org/immunotherapy/cancer-types/stomach-cancer (accessed 20 January 2020).

Davis, B. P., Rothenberg, M. E. (2014). Eosinophils and cancer. Cancer Immunol. Res., 2, 1-8.

Dorta, R. G., Landman, G., Kowalski, L. P., Lauris, J. R., Latorre, M. R., Oliveira, D. T. (2002). Tumour-associated tissue eosinophilia as a prognostic factor in oral squamous cell carcinomas. Histopathology, 41, 152-157.

Edge, S. B., Byrd, D. R., Compton, C. C., Fritz, A. G., Greene, F. L., Trotti, A. (2010). AJCC Cancer Staging Manual. $7^{\text {th }}$ edn. Springer. 672 pp.

Gregory, A. D., Houghton, A. Mc G. Tumor-associated neutrophils: New targets for cancer therapy. Cancer Res., 71 (7), 2411-2416.

Hendry, S., Salgado, R., Gevaert, T., ... Russell, P. A., John, T., Thapa, B., Christie, M., van de Vijver, K., Estrada, M. V., Gonzalez-Ericsson, P. I., et al. (2017). Assessing tumor-infiltrating lymphocytes in solid tumors: A practical review for pathologists and proposal for a standardized method from the International Immuno-Oncology Biomarkers Working Group: Part 2: TILs in melanoma, gastrointestinal tract carcinomas, non-small cell lung carcinoma and mesothelioma, endometrial and ovarian carcinomas, squamous cell carcinoma of the head and neck, genitourinary carcinomas, and primary braint. Adv. Anat. Pathol., 24 (6), 311-335.

Hiramatsu, S., Tanaka, H., Nishimura, J., Sakimura, C., Tamura, T., Toyokawa, T., Muguruma, K., Yashiro, M., Hirakawa, K., Ohira, M. (2018). Neutrophils in primary gastric tumors are correlated with neutrophil infiltration in tumor-draining lymph nodes and the systemic inflammatory response. BMC Immunol., 19 (1), 13.

Huang, L., Appleton, J. A. (2016). Eosinophils in helminth infection: Defenders and dupes. Trends Parasitol., 32 (10), 798-807.

Huh, S. J., Liang, S., Sharma, A., Dong, C., Robertson, G. P. (2010). Transiently entrapped circulating tumor cells interact with neutrophils to facilitate lung metastasis development. Cancer Res., 70, 6071-6082.

Jablonska, J., Lang, S., Sionov, R. V., Granot, Z. (2017). The regulation of pre-metastatic niche formation by neutrophils. Oncotarget, 8 (67), 112132-112144.

Jensen, H. K., Donskov, F., Marcussen, N., Nordsmark, M., Lundbeck, F., von der Maase, H. (2009). Presence of intratumoral neutrophils is an independent prognostic factor in localized renal cell carcinoma. J. Clin. Oncol., 27, 4709-4717.

Kang, B. W., Seo, A. N., Yoon, S., Bae, H. I., Jeon, S. W., Kwon, O. K., Chung, H. Y., Yu, W., Kang, H., Kim, J. G. (2016). Prognostic value of tumor-infiltrating lymphocytes in Epstein-Barr virus-associated gastric cancer. Ann. Oncol., 27, 494-501.

Kim, R., Emi, M., Tanabe, K. (2007). Cancer immunoediting from immune surveillance to immune escape. Immunology, 121, 1-14.

Kita, H. (1996). The eosinophil: A cytokine-producing cell? J. Allergy Clinical Immunol., 97 (4), 889-892.

Laurén, P. (1965). The two histological main types of gastric carcinoma: Diffuse and so-called intestinal-type carcinoma. Acta Pathol. Microbiol. Scand., 64, 31-49.
Lauwers, G. Y., Carneiro, F., Graham, D. Y. (2010). Gastric carcinoma. In: Bowman, F. T, Carneiro, F, Hruban, R. H. (eds.) Classification of Tumours of the Digestive System. IARC, Lyon.

Lee, J. S., Won, H. S., Sun, D. S., Hong, J. H., Ko, Y. H. (2018). Prognostic role of tumor-infiltrating lymphocytes in gastric cancer. Medicine, 97 (32), e11769.

Lorena, S. C., Oliveira, D. T., Dorta, R. G., Landman, G., Kowalski, L. P. (2003). Eotaxin expression in oral squamous cell carcinomas with and without tumour associated tissue eosinophilia. Oral Dis., 9 (6), 279-283.

Lotfi, R., Lee, J. J., Lotze, M. T. (2007). Eosinophilic granulocytes and damage-associated molecular pattern molecules (DAMPs): Role in the inflammatory response within tumors. J. Immunother., 30, 16-28.

Mezale, D., Strumfa, I., Vanags, A., Mezals, M., Fridrihsone, I., Strumfs, B., Balodis, D. (2017). Non-alcoholic steatohepatitis, liver cirrhosis and hepatocellular carcinoma: The molecular pathways. In: Liver Cirrhosis: Update and Current Challenges. InTech, London.

Naito, Y., Saito, K., Shiiba, K., Ohuchi, A., Saigenji, K., Nagura, H., Ohtani, H. (1998). CD8+ T cells infiltrated within cancer cell nests as a prognostic factor in human colorectal cancer. Cancer Res., 58, 3491-3494.

Nelson, B. H. (2010). Tumor-infiltrating lymphocytes B cells: The other CD20+. J. Immunol., 185, 4977-4982.

Nielsen, H. J., Hansen, U., Christensen, I. J., Reimert, C., Brunner, N., Moesgaard, F. (1999). Independent prognostic value of eosinophil and mast cell infiltration in colorectal cancer tissue. J. Pathol., 189, 487-495.

Pages, F., Kirilovsky, A., Mlecnik, B., Asslaber, M., Tosolini, M., Bindea, G., Lagorce, C., Wind, P., Marliot, F., Bruneval, P., Zatloukal, K., Trajanoski, Z., Berger, A., Fridman, W. H., Galon, J. (2009). In situ cytotoxic and memory $\mathrm{T}$ cells predict outcome in patients with early-stage colorectal cancer. J. Clin. Oncol., 27, 5944-5951.

Piazuelo, M. B., Camargo, M. C., Mera, R. M., Delgado, A. G., Peek, R. M., Jr., Correa, H., Schneider, B. G., Sicinschi, L. A., Mora, Y., Bravo, L. E., Correa, P. (2008). Eosinophils and mast cells in chronic gastritis: Possible implications in carcinogenesis. Hum. Pathol., 39 (9), 1360-1369.

Piazuelo, M. B., Riechelmann, R. P., Wilson, K. T., Algood, H. M. S. (2019). Resolution of gastric cancer-promoting inflammation: A novel strategy for anti-cancer therapy. Curr. Top Microbiol. Immunol., 421, 319-359.

Rathore, A. S., Kumar, S., Konwar, R., Makker, A., Negi, M. P., Goel, M. M. (2014). CD3+, CD4+ \& CD8+ tumour infiltrating lymphocytes (TILs) are predictors of favourable survival outcome in infiltrating ductal carcinoma of breast. Indian J. Med. Res., 140, 361-369.

Rothenberg, M. E., Hogan, S. P. (2006). The eosinophil. Ann. Rev. Immunol., 24, 147-174.

Rumba, R., Vanags, A., Kalva, A., Bogdanova, T., Drike, I., Mezale, D., Vitola, M., Gardovskis, J., Strumfa, I. (2017). Surgical management of malignant gastric tumours: A practical guide. In: Gastric Cancer. InTech, London.

Scanlan, M. J., Gure, A. O., Jungbluth, A. A., Old, L. J., Chen, Y. T. (2002). Cancer/testis antigens: An expanding family of targets for cancer immunotherapy. Immunol. Rev., 188, 22-32.

Schmidt, H., Bastholt, L., Geertsen, P., Christensen, I. J., Larsen, S., Gehl, J., von der Maase, H. (2005). Elevated neutrophil and monocyte count in peripheral blood are associated with poor survival in patients with metastatic melanoma: A prognostic model. Brit. J. Canc., 93 (3), 273-278.

Silovs, A., Strumfa, I., Riekstins, R., Simtniece, Z., Vanags, A., Gardovskis, J. (2018). Systemic inflammatory response in pancreatic ductal adenocarcinoma. In: Advances in Pancreatic Cancer. InTech, London.

Strumfa, I., Bogdanova, T., Kalva, A., Strumfs, B., Rumba, R., Vanags, A., Drike, I., Mezale, D., Abolins, A., Jakovlevs, A., Balodis, D., Gardovskis, J. (2017). Systemic inflammatory reaction in gastric cancer: Biology and practical implications of neutrophil to lymphocyte ratio, Glasgow prognostic score and related parameters. In: Gastric Cancer. InTech, London. 
Suzuki, H., Chikazawa, N., Tasaka, T., Wada, J., Yamasaki, A., Kitaura, Y., Sozaki, M., Tanaka, M., Onoishi, H., Morisaki, T., Katano, M. (2010). Intratumoral CD8(+) T/FOXP3(+) cell ratio is a predictive marker for survival in patient with colorectal cancer. Cancer Immunol. Immunother., 59, 653-661.

Tecchio, C., Scapini, P., Pizzolo, G., Cassatella, M. A. (2013). On the cytokines produced by human neutrophils in tumors. Seminars Cancer Biol., 23 (3), 159-170.

Teruya-Feldstein, J., Jaffe, E. S., Burd, P. R., Kingma, D. W., Sersuda, J. E., Tosato, G. (1999). Differential chemokine expression in tissues involved by Hodgkin's disease: Direct correlation of eotaxin expression and tissue eosinophilia. Blood, 93, 2463-2470.

Uribe-Querol, E., Rosales, C. (2015). Neutrophils in cancer: Two sides of the same coin. J. Immunol. Res., 2015, 983698.

Varricchi, G., Bagnasco, D., Borriello, F., Heffler, E., Canonica, G. W. (2016). Interleukin-5 pathway inhibition in the treatment of eosinophilic respiratory disorders: Evidence and unmet needs. Curr. Opin. Allergy Clin. Immunol., 16 (2), 186-200.

Varricchi, G., Galdiero, M. R., Loffredo, S., Lucarini, V., Marone, G., Mattei, F., Schiavoni, G. (2000). Eosinophils: The unsung heroes in cancer? Oncoimmunology, 7 (2), e1393134.

Von Wasielewski, R., Seth, S., Franklin, J., Fischer, R., Hubner, K., Hansmann, M. L., Diehl, V., Georgii, A. (2000). Tissue eosinophilia corre- lates with poor prognosis in nodular sclerosing Hodgkins disease, allowing for know prognostic factors. Blood, 95 (4), 1207-1213.

Wang, X., Liu, Y., Diao, Y., Gao, N., Wan, Y., Zhong, J., Zheng, H., Wang, Z., Jin, G. (2018). Gastric cancer vaccines synthesized using a TLR7 agonist and their synergistic antitumor effects with 5-fluorouracil. J. Transl. Med., 16 (1), 120.

Welch, D. R., Schissel, D. J., Howrey, R. P., Abeed, P. A. (1989). Tumor-elicited polymorphonuclear cells, in contrast to "normal" circulating polymorphonuclear cells, stimulate invasive and metastatic potentials of rat mammary adenocarcinoma cells. Proc. Natl. Acad. Sci. USA, 86, 5859-5863.

Xie, F., Liu, L. B., Shang, W. Q., Chang, K. K., Menh, Y. H., Mei, J., Yu, J. J., Li, D. J., Li, M. Q. (2015). The infiltration and functional regulation of eosinophils induced by TSLP promote the proliferation of cervical cancer cell. Cancer Lett., 364 (2), 106-117.

Yousefi, S., Gold, J. A., Andina, N., Lee, J. L., Kelly, A. M., Kozlowski, E., Schmid, I., Straumann, A., Reichenbac, J., Gleich, G., J., Simon H.-U., et al. (2008). Catapult-like release of mitochondrial DNA by eosinophils contributes to antibacterial defense. Nat. Med., 14 (9), 949-953.

Zhao, J.-J., Pan, K., Wang, W., Chen, J. G., Wu, Y. H., Lv, L., Li, J. J., Chen, Y. B., Wang, D. D., Pan, Q. Z., Li, X. D., Xia, J. C., et al. (2012). The prognostic value of tumor-infiltrating neutrophils in gastric adenocarcinoma after resection. PLOS ONE, 2012, 7 (3), e33655.

\section{IEKAISUMA ŠŪNAS KUN̦ĢA VĒŽA AUDOS: AUDZĒJA AUGŠANU VEICINOŠAS VAI ORGANISMA SARGI?}

Retrospektīvā pētījumā tika analizēti kuṇǵa vēža morfoloǵiskie parametri, lai precizētu to saistību ar audzēju infiltrējošo iekaisuma šūnu noteiktiem veidiem, kā arī klīniskiem un/vai patoloğiskiem raksturlielumiem. Sekojoši parametri — pacientu vecums, dzimums, audzēja lokālā izplatība (pT), metastāzes limfmezglos (pN), audzēja diferenciācijas pakāpe $(\mathrm{G})$, kā arī audzēja histoǵenēze atbilstoši Pasaules Veselības organizācijas (PVO) un Laurena (Lauren) klasifikācijām - tika noteikti 211 ķirurǵiski operētos kuņǵa vēža gadījumos. Audzēja infiltrējošās iekaisuma šūnas, ieskaitot eozinofilos un neitrofilos leikocītus, kā arī limfocītus, tika kvantitatīvi noteiktas audzēja stromā piecos brīvi izvēlētos reprezentatīvos augsta palielinājuma redzes laukos. Statistiskai apstrādei tika izmantoti Manna-Vitnija (Mann-Whitney) un Kruskala-Vallisa (Kruskal-Wallis) testi; atšķirības tika uzskatītas par statistiski ticamām, ja $p<0,05$. Eozinofilo leikocītu infiltrācija audzēja stromā bija statistiski ticami intensīvāka adenokarcinomu audos un gadījumos, kur audzēja metastāzes limfmezglos netika konstatētas (atbilstošās $p$ vērtības: $p=0,005$ un $p=0,002$ ). Augstāks neitrofilo leikocītu skaits audzēja stromā konstatēts pacientiem vecuma grupā līdz 65 gadiem, kā arī intestināla tipa kuṇga vēža audos ( $p=0,029$ un $p=0,007)$. Audzēja stromālo limfocītu infiltrācija neuzrādīja statistiski nozīmīgas saistības ar klīniskiem vai morfoloğiskiem datiem. Tādējādi mūsu pētījums izgaismo saikni starp noteiktām iedzimtās imūnās sistēmas šūnām un kuṇǵa karcinomas morfoloğiskajām iezīmēm. 